\title{
Flower and ornamental plant consumers profile and behavior
}

\author{
Patrícia Duarte de Oliveira Paiva ${ }^{1 *} \mathbb{D}$, Michele Valquíria dos Reis ${ }^{1}\left(\mathbb{D}\right.$, Gabriela Silva Sant'Ana $^{1}$ (), \\ Francilene de Lourdes Bonifácio ${ }^{1}\left[\right.$, Paulo Henrique Sales Guimarães ${ }^{2}$ (i) \\ ${ }^{1}$ Universidade Federal de Lavras (UFLA), Departamento de Agricultura, Lavras-MG, Brazil.
${ }^{2}$ Universidade Federal de Lavras (UFLA), Departamento de Estatística, Lavras-MG, Brazil.
}

\begin{abstract}
Due to the importance of the flower and ornamental plants sector in Brazilian agribusiness, studies that analyze the situation of its different segments can help to understand and establish policies and actions that support and stimulate their development. The objective was to analyze the profile and behavior of consumers in the productive chain of flowers and ornamental plants. For this, a questionnaire with direct questions was prepared and directed to consumers of flowers and ornamental plants. The application was made personally with direct approaches in places of great movement and specialized technological fairs, and also online through social media, using Google platform. The results were analyzed by comparing qualitative variables using the Chi-Square test. It was identified that the profile of consumers is concentrated in women who live in large cities, consuming an average of R $\$ 100.00$ to $\mathrm{R} \$ 200.00$ over a period of one year.
\end{abstract}

Keywords: agribusiness, floriculture production chain, ornamental flowers and plants market.

\section{Resumo}

Perfil e comportamento dos consumidores de flores e plantas ornamentais

Em função da importância do setor de flores e plantas ornamentais no agronegócio brasileiro, estudos que analisam a situação de seus diferentes segmentos podem auxiliar a entender e estabelecer políticas e ações que apoiem e estimulem o seu desenvolvimento. Objetivou-se analisar o perfil e comportamento dos consumidores da cadeia produtiva de flores e plantas ornamentais. Para isso, foi elaborado um questionário com perguntas diretas e direcionado aos consumidores de flores e plantas ornamentais. A aplicação foi feita pessoalmente com abordagens direta em locais de grande movimento e feiras tecnológicas da área e, ainda, por meio de mídias sociais, utilizando a plataforma Google. Os resultados foram analisados comparando as variáveis qualitativas utilizando o teste Qui-Quadrado. Identificou-se que o perfil dos consumidores está concentrado em mulheres que vivem em cidades de grande porte, consumindo em média de R\$100,00 a R \$200,00 no período de um ano.

Palavras-chave: agronegócio, cadeia produtiva de floricultura, mercado de flores e plantas ornamentais.

\section{Introduction}

The production chain of floriculture is composed of growers and producers, wholesale, retailers and consumers (Paiva, 2018). Each one of these sectors has an important role in the production chain to function well. The demands of the consumer are normally transferred and adhered to the other segments and, in this way, a raise occurs (Olewnicki et al., 2019).

In Brazil, the consumer sector of flowers and ornamental plant has gradually developed. This raise is linked to several factors such as the increase in a job opportunity, providing an improvement in income and a general increase in product consumption which also brings expansion to the consumption of flowers. Associated with this, there is an increase in the wholesale market of flowers and ornamental plant, expanding commercialization of these products (Silva et al., 2015). With this, the best products available in the retail market as flower shops, supermarkets, and others are visible, attracting and better attending the clients (Junqueira and Peetz, 2014). Also is important to add that the consumption may be related

*Corresponding author: patriciapaiva@ufla.br 
to gender and age (Lakshmi et al., 2017; Anacleto et al., $2017 \mathrm{~b}$ ). Relating the behavior in a purchase to the gender, women look for more interaction, tending to be focus on people (Lakshmi et al., 2017) leading to be very important the treatment of the employees.

Since flowers are better at inducing positive emotions, people discover that is a good and important consumer of this product (Huss et al., 2017). The habit of purchase flower and ornamental plants has become more common, reflecting on increasing per capita consumption. In year 2000, the consumption per capita was R\$20.003 on average and in 2018 it was registered $\mathrm{R} \$ 31.50^{4}$, an increase of $63.4 \%$. Thus, even with the economic crisis and unemployment, the agribusiness floriculture grew by $7 \%$ in 2018 compared to 2017 . The sales value estimated by IBRAFLOR in 2018 was R\$ 8 billion (Boehm, 2018). Along with this, the technological development such as the internet and social media required a reinvention in the form of sales (Junqueira and Peetz, 2017). Another issue to consider is that in one local survey has been identified that women and people age of 20-44 are the main flower buyers in flower shops (Anacleto et al., 2017a), which is necessary to be extended and get a confirmation for other regions in the country.

The sales are concentrated on commemorative dates, with greater demand on Mother's Day, All Souls' Day, Christmas and Valentine's Day. In these periods, the retails are request to offer greater supply and diversity of products to serve the consumer market (Ceratti et al., 2007). But also, over the years, there are records of the increase in self-consumer in different locations (Palma et al., 2011).

There are different profiles of the consumers of flower and ornamental plant, which can be divided into four groups: the first one is composed by those who purchase the product due to romanticism, to express affection, mysticism or even to reduce stress; the second group, acquires the product based on symbolism and conquest. The third one acquires flowers and ornamental plants for embellishment and ornamentation and. The fourth is characterized as the consumer of promotion, that is, the one who purchases the product due to some type of commemorative date (Aki, 2002). But one hypothesis is that over the years may be changed and consumption should be linked to gender (Lakshmi et al., 2017, Anacleto et al., 2017b), income, age, besides preferences. Another issue that should be considered is the employees behavior and structure, and also, another more recent possibility for purchase using technologies as for online shopping (Lissitsa and Kol, 2016; Junqueira and Peetz, 2017).

With this, the aim was to better understand the consumption segment in a production chain of flower and ornamental plant, considering the profile and behavior of the consumers.

\section{Material and Methods}

The research was carried out in order to know the profile and performance of consumers in a production chain of flowers and ornamental plant having been interviewed 1047 people, of different ages, gender, social classes, covering all regions of Brazil.

The forms were designed to direct the questions and the application was in person and online. People were interviewed on their home, work, universities, during specialized fairs as Hortitec, Enflor, and Garden Fair, besides high flow locations as streets, bus stations, and airports.

Wide dissemination was also made on social media such as Facebook, Instagram, and e-mails with support from Sociedade Brasileira de Floricultura e Plantas Ornamentais. The aim was to reach a large number of responses, with a diversity of responses and origin from different regions of the country.

The questionnaires online were available online by using the Google platform (Google Forms), using a specific link. The survey period ranged from September 2017 to September 2018. Aiming for impartial results, respondents were not identified.

The questions and answers were prepared in simple language, without the use of technical terms, facilitation understanding to avoid any type of mistake. Most of the questions had direct, single or multiple answers, but for some, depending on the theme, it was possible a free answer.

Concerning the questions to characterize the profile of consumers of flowers and ornamental plants, the objective was to characterize them in detail, for that a detailed questions were described on Table 1.

\footnotetext{
${ }^{3}$ Minimum salary in 2000: R\$ $151.00=$ USD: 75.40

${ }^{4}$ Minimum salary in 2018: R\$ $954.00=$ USD: 269.92
} 
Table 1. The performed survey: questions and possible answers.

\begin{tabular}{|c|c|}
\hline Question & Possible answers \\
\hline \multicolumn{2}{|c|}{ Personnel information } \\
\hline Which is your profession? & Free response \\
\hline Inform your age group & $\begin{array}{l}\text { Up to } 20 \text { years } \\
21 \text { to } 30 \text { years } \\
31 \text { to } 40 \text { years } \\
41 \text { to } 50 \text { years } \\
50 \text { to } 60 \text { years } \\
61 \text { to } 70 \text { years } \\
71 \text { to } 80 \text { years } \\
\text { Above } 80 \text { years }\end{array}$ \\
\hline Please, inform your family monthly income & $\begin{array}{l}\text { Up to } R \$ 2,000 \\
R \$ 2,000-R \$ 5,000 \\
R \$ 5,000-R \$ 10,000 \\
R \$ 10,000-R \$ 15,000 \\
R \$ 15,000-R \$ 20,000 \\
\text { Above } R \$ 20,000\end{array}$ \\
\hline Indicate your gender & $\begin{array}{l}\text { Female } \\
\text { Male } \\
\text { I prefer not to inform }\end{array}$ \\
\hline Indicate your state & A list of states was provide \\
\hline Please, select the number of inhabitants of the city that you live & $\begin{array}{l}\text { Up to } 10,000 \text { inhabitants } \\
10,000 \text { to } 50,000 \\
50,000 \text { to } 100,000 \\
100,000 \text { to } 200,000 \\
200,000 \text { to } 500,000 \\
500,000 \text { to } 1,000,000 \\
1,000,000 \text { to } 5,000,000 \\
5,000,000 \text { to } 10,000,000 \\
\text { Above } 10,000,000\end{array}$ \\
\hline
\end{tabular}

\section{Habit of flower consumption}

Concerning a period of one year (2016 per example), in average, how I do no buy this products much did you spend with flowers and ornamental plant?

$\mathrm{R} \$ 5.00$ - R\$ 20.00

$\mathrm{R} \$ 20.00$ - R\$50.00

$\mathrm{R} \$ 50.00-\mathrm{R} \$ 100.00$

$\mathrm{R} \$ 100.00-\mathrm{R} \$ 200.00$

$\mathrm{R} \$ 200.00-\mathrm{R} \$ 500.00$

Above R\$500.00

What could stimulate and increase flower consumption (multiple responses)

I do not like to buy flowers

I have no interest in spending more with flowers

I think I already buy enough

The availability of more stores or sales points

If my salary was higher

Greater product availability

Lower prices

Do you usually buy flowers for your home?

Never thought about that

Always! I like to decorate my home with flowers

I would like, but I do not have enough money

I buy only for special occasions

I prefer the artificial ones, since it is forever

Other: 
Table 1. cont.

\begin{tabular}{|c|c|}
\hline $\begin{array}{l}\text { Which type of ornamental plant do you like more to purchase (Multi- } \\
\text { ple responses) }\end{array}$ & $\begin{array}{l}\text { I do not have the habit of buying flowers } \\
\text { Cut flowers } \\
\text { Cut foliage } \\
\text { Garden seedlings } \\
\text { Orchids } \\
\text { Potted flowers } \\
\text { Succulents } \\
\text { Other: }\end{array}$ \\
\hline \multicolumn{2}{|c|}{ Knowing about a consumption profile } \\
\hline Period of the year that you mostly buy flowers and ornamental plant & $\begin{array}{l}\text { All Souls Day } \\
\text { Father's Day } \\
\text { Mother's Day } \\
\text { New Year celebration } \\
\text { Valentine's Day } \\
\text { Woman's Day } \\
\text { I buy all over the year, regardless of the date } \\
\text { I do not usually buy flowers } \\
\text { I rarely buy flowers }\end{array}$ \\
\hline Preferred locations for buying flowers and ornamental plant & $\begin{array}{l}\text { By phone } \\
\text { Stores in shopping malls } \\
\text { Social networks } \\
\text { Kiosks in squares } \\
\text { I do not buy flowers } \\
\text { Garden centers } \\
\text { Local producer's fair } \\
\text { Supermarket } \\
\text { Flower shops }\end{array}$ \\
\hline Factors that you dislike more in a flower shop & $\begin{array}{l}\text { Unwillingness of employees to attend } \\
\text { Employee distraction } \\
\text { Dirty place } \\
\text { Abusive prices } \\
\text { Delay in attendance } \\
\text { Disorganized place } \\
\text { Location of the Point of Sale }\end{array}$ \\
\hline $\begin{array}{l}\text { Inform your average spent during a flower and ornamental plant pur- } \\
\text { chase }\end{array}$ & $\begin{array}{l}\text { I did not buy this product } \\
\mathrm{R} \$ 5.00-\mathrm{R} \$ 20.00 \\
\mathrm{R} \$ 20.00-\mathrm{R} \$ 50.00 \\
\mathrm{R} \$ 50.00-\mathrm{R} \$ 100.00 \\
\mathrm{R} \$ 100.00-\mathrm{R} \$ 200.00 \\
\mathrm{R} \$ 200.00-\mathrm{R} \$ 500.00 \\
\text { Above } \mathrm{R} \$ 500.00\end{array}$ \\
\hline $\begin{array}{l}\text { Level of your knowledge in relation to the flowers' and ornamental } \\
\text { plants' names }\end{array}$ & $\begin{array}{l}\text { Nothing } \\
\text { Few knowledge } \\
\text { I know a lot } \\
\text { I am an expert at this! }\end{array}$ \\
\hline $\begin{array}{l}\text { Factors that please you in a flower shop during a purchase (Multiple } \\
\text { responses) }\end{array}$ & $\begin{array}{l}\text { Employees who understand the product and answer ques- } \\
\text { tions } \\
\text { Good prices } \\
\text { Attention of employees during the attendance } \\
\text { Clean and organizes place }\end{array}$ \\
\hline $\begin{array}{l}\text { Do your ever buy flowers and ornamental plant online? (Multiple } \\
\text { responses) }\end{array}$ & $\begin{array}{l}\text { I only buy online } \\
\text { I have already bought it online } \\
\text { I have never heard about that } \\
\text { I have already visited sites, but I have never bought. } \\
\text { I know about it, but I have never visited a website }\end{array}$ \\
\hline
\end{tabular}


The age scale used was divided in each 10 years, allowing to analyze the behavior in more detailed way, concerning the age groups and correlate with the different generations (Lissitsa et al., 2016).

The family monthly income was based on directions of ABEP for economical classification (ABEP, 2018).

The data collected and recorded through the questionnaires were compiled and analyzed. The questions were evaluated using the statistical software, R Core Team, associating qualitative variables (Chi-Square Test, Relative Risk, and Chance Ratio). The results were displayed in graphs and tables and interpreted.

\section{Results and Discussion}

The research aimed to identify the profile of the
Brazilian consumers of flowers and ornamental plant. For that, responses were recorded from all regions of the country, although the majority, $66.6 \%$, corresponded to consumers in the Southeast region. In addition, consumers also reported on the size of the city in which they live, being $10.5 \%$ in small cities, $18.9 \%$ in medium-sized cities, and $70.6 \%$ in large cities.

Considering the gender, $65.5 \%$ were women and $34.5 \%$ men, performing a majority of the female gender, as also observed in a study focus on a specific Brazilian region (Anacleto et al., 2017b). The age of the respondents, there were responses from all age groups, although most were between 21 and 50 years-old (Figure 1). The age scale used was divided in each 10 years, allowing to analyze the behavior in more detailed way, concerning the age groups and generations.

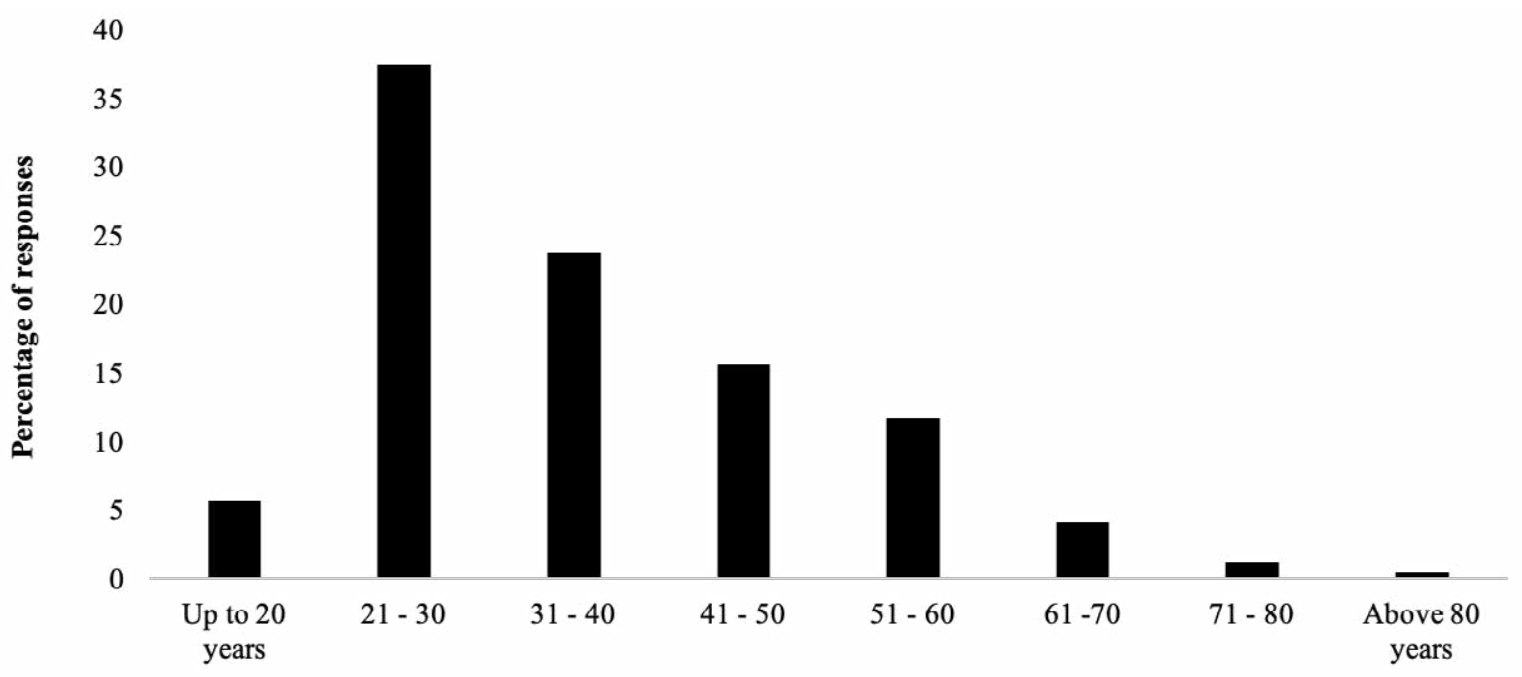

Figure 1. The age group of survey respondents (consumers).

It is interesting to note that besides the majority of the respondents corresponds to young people, aged 21 to 30 , there were responds over 60 -years. This may contribute a lot for the survey, catching opinions from this group, since the elderly have been showing a tendency to increase the consumption of flowers (Aki and Perosa, 2002).
Considering the family monthly income, $53.7 \%$ of the respondents reported an income between $\mathrm{R} \$ 2,000.00$ and $\mathrm{R} \$ 10,000.00$ monthly, although there were respondents in all income groups (Figure 2). 


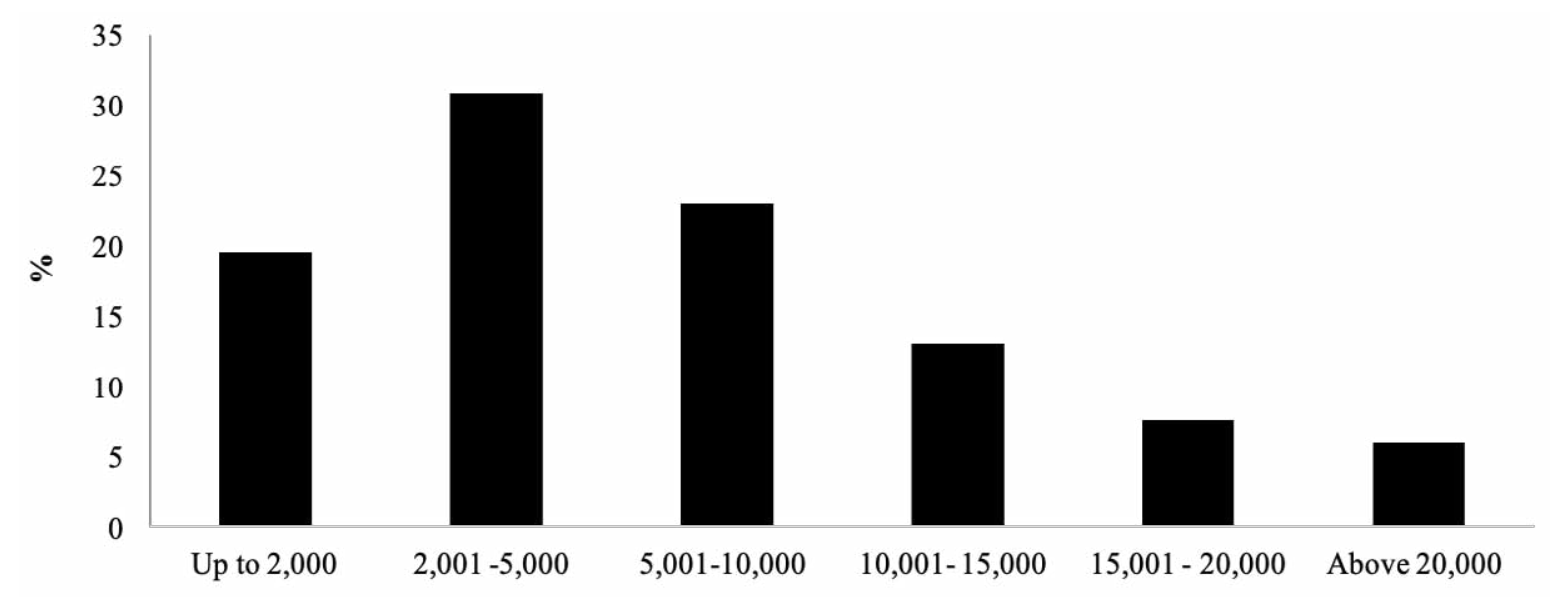

Figure 2. Average income range $(\mathrm{R} \$)$ of the consumers interviewed.

Concerning the average money spent with flowers and ornamental plants, the responses of the participants were evaluated relating the value spent along the year with the average monthly income. It was observed that for those that receive the higher income, present greater money spent on flowers and ornamental plant (Figure 3), as it was expected, and confirm this statement.

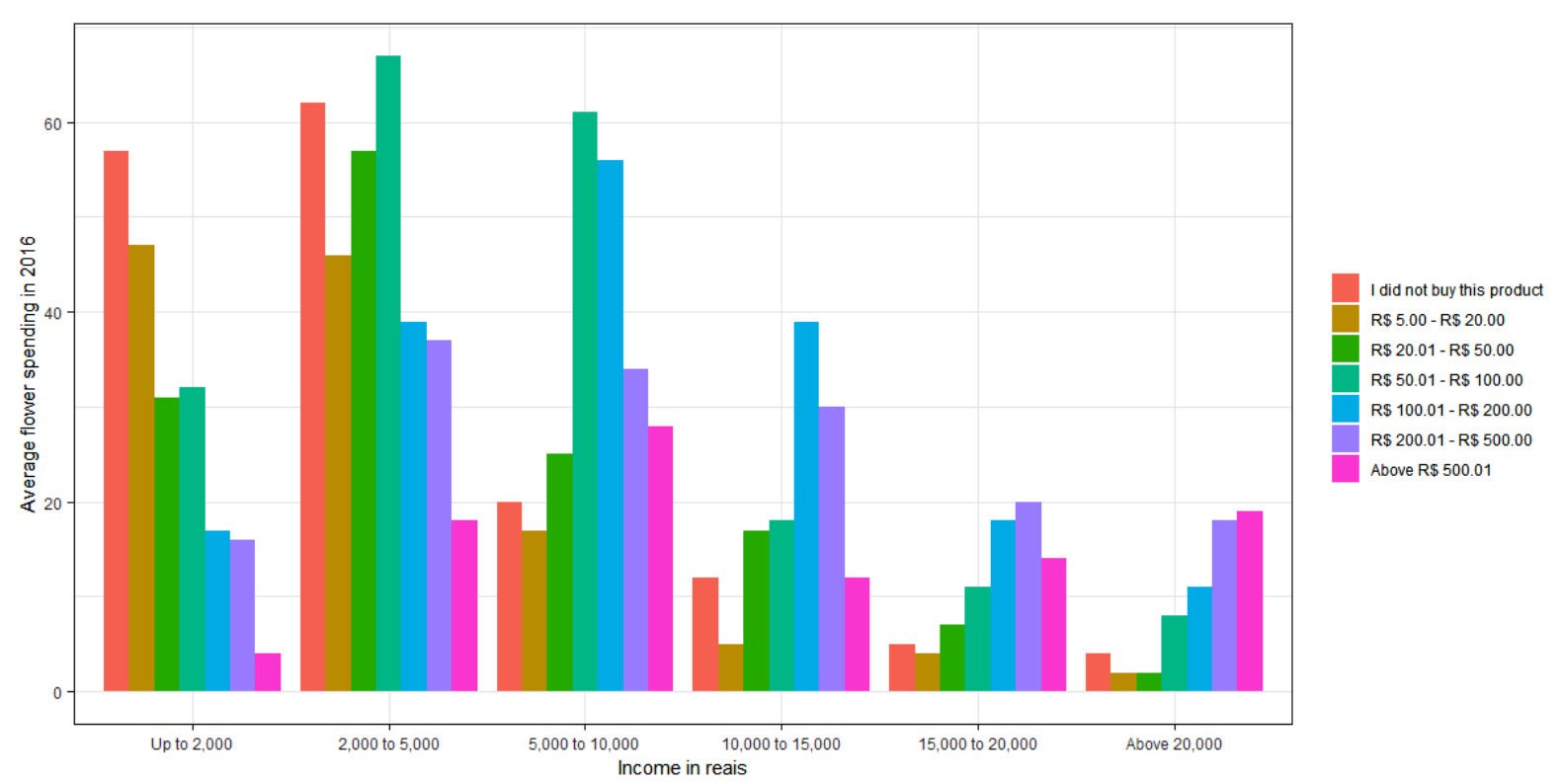

Figure 3. Relation between respondents' income (R\$) and average money spent on flowers and ornamental plants.

Flowers and ornamental plant are not considered as items of basic need, therefore, when comparing the average spent with the respondents' monthly income, most of those who have an income of up to $\mathrm{R} \$ 5,000.00$ a month indicated that they did not spend on these products. Indeed, comparing those that the monthly income is up to $\mathrm{R} \$ 2,000.00$ and the subsequent group, $\mathrm{R} \$$ 2,000.00-R $\$ 5,000.00$, a low increase on income allow to increase a flower and ornamental plant consumption, spending around $\mathrm{R} \$ 20.00-\mathrm{R} \$ 100.00$. Respondents with an average income over than $\mathrm{R} \$ 5,000.00$, on the other hand, tending to spent more with the flower market, raising the value as the increase of the monthly income. The forecast for the next years up to 2030 is an increase on purchasing power of the middle class, and for that will be a likely drive on the demand for ornamentals in Brazil (AIPH, 2019). The share of respondents who have an income above $\mathrm{R} \$ 20$ thousand a month is the same as of the respondents who spent over R $\$ 500.00$ in these products over a year period.

Relating the gender and the average amount spent with flowers and ornamental plants, observing that women spend a higher amount than men, agreeing with Anacleto et al. (2017a) observations. On average, women spend 
in average, $\mathrm{R} \$ 100.00$ to $\mathrm{R} \$ 200.00$ over a period of one year with flower and ornamental plant products, and men, around the half, R\$ 50.00 to R\$ 100.00 (Figure 4). Even though men have a lower consumption value than women, there is still a cultural tradition for men to gift women with flowers. This may be observed when we considered the percentage of women that answer "I did not buy this product" which is higher than men.

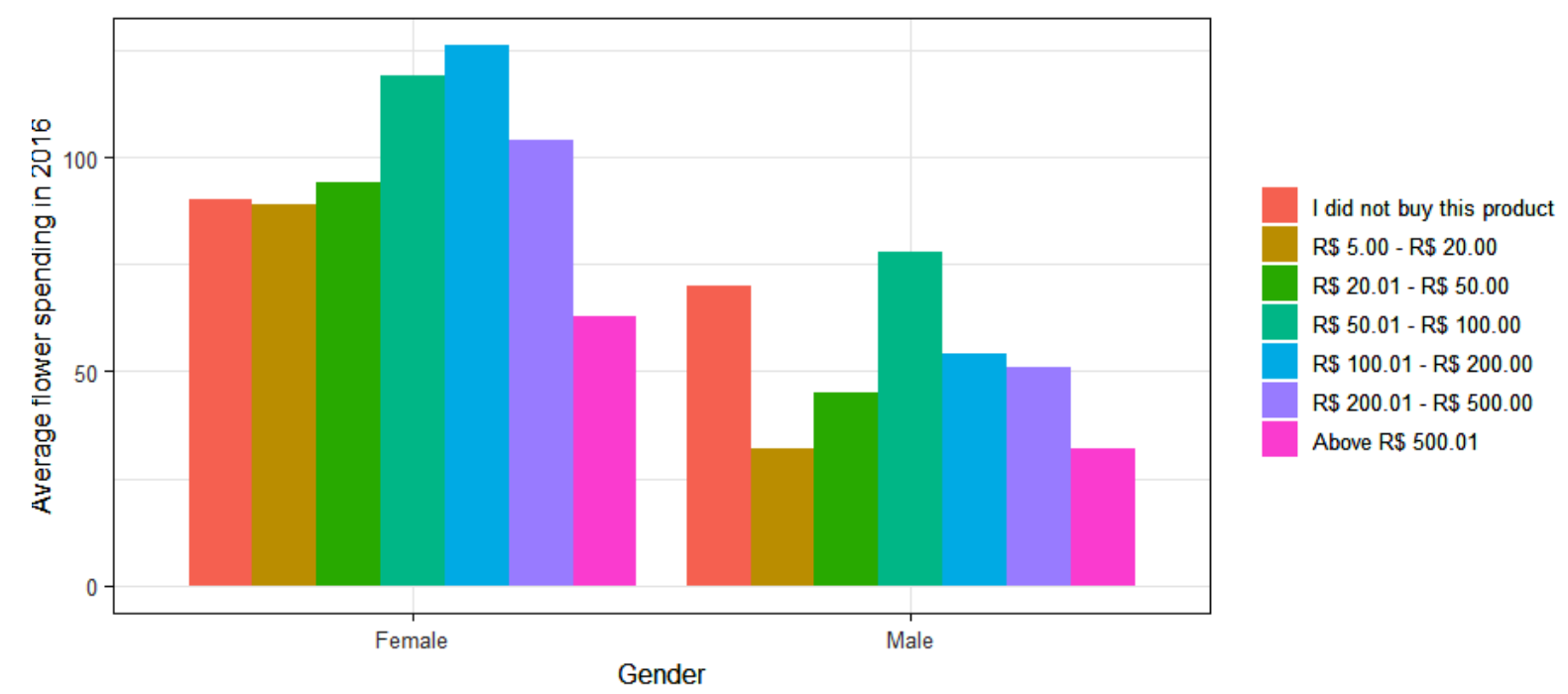

Figure 4. Relation between gender and average spent (R\$) with flowers and ornamental plant

Therefore, even acquiring products of low price, most of the respondents, within a year, at least, bought some type of flowers and ornamental plant products. The Brazilian per capita value of flower consumption is $\mathrm{R} \$ 31.50$, which is not an expressive value if compared to other countries (Junqueira and Peetz, 2017). In this research, it was possible to notice that for a greater number of the respondents (18.9\%) the average amount spent is greater than the value of the per capita of consumption, been around $\mathrm{R} \$ 50.00$ and $\mathrm{R} \$ 100.00$ a year. In addition to the estimated value, respondents were asked to indicate what products they buy more frequently, as a way of identifying consumer preferences. Pot plants and plants for gardening are the most acquiring products, followed by cut flowers (Figure 5).

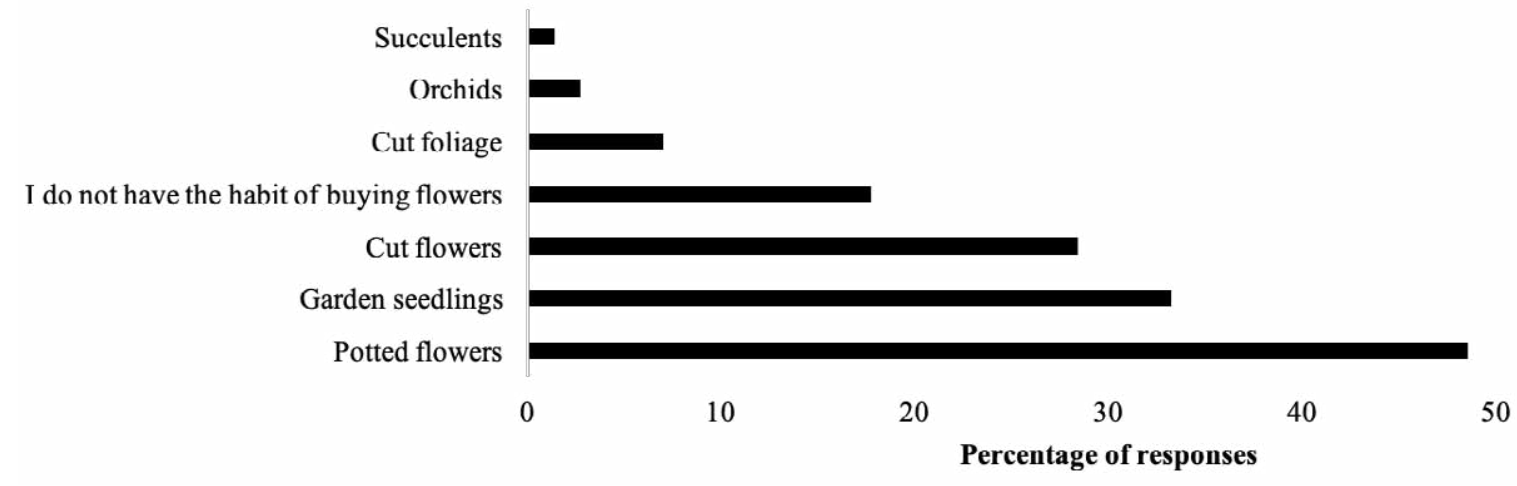

Figure 5. Most purchased flower and ornamental plant products according to consumers (multiple responses).

According to the flower shop owners, the most sold products are traditional cut flowers, such as roses, chrysanthemums, alstroemerias, etc., followed by pot plants and garden plants (Junqueira and Peetz, 2017). On the other hand, the interviewers answered that the most purchased items are potted flowers. This difference can be understood by the fact that pot plants have greater durability and practicality in care, such as orchids and succulents and maybe consumers remember more this acquisition. In addition, some owners of flower shops also have decorators as clients, who mostly consume a large quantity of cut flowers.

The interviewers had a chance to inform in "Other" some products that they also use to buy in flower shops, 
different from the list provide on the survey. Some products are chosen by less than $1 \%$, as orchids, bulbs, turfgrass, palm trees, bromeliads, and medicinal plants. The reason for this may be that turfgrass, medicinal plants and palm trees are common products sold by nurseries. Orchids and bromeliads are specific types of pot plants.

Consumers were also asked about what could stimulate and increase flower consumption according to their view (Figure 6).



Figure 6. Situations that may encourage greater consumption of flower and ornamental plant according to consumers' view (multiple responses).

Among respondents, $30.8 \%$ stated that they would buy more if the products had the lowest cost. This is a result of a culture statement in which, unfortunately, flowers and ornamental plant are considered expensive products and not essential for daily life. On the other hand, lower prices may reflect in limitations for the producers. Analyzing the monthly income and flower and ornamental plant acquisition, an expressive percentage (above 60\%) of the responds that receives up to $\mathrm{R} \$ 5,000.00$, indicated that they do not buy these products (Figure 3 ).

Greater availability of products was appointed by $19.6 \%$ of the responders, as an issue that stimulates them to raise their purchases. This is an indication that flower shop owners need to diversify more and offer different options to retain a greater number of customers. But for the retails, a great diversity of products sometimes represent a problem since the may not be sold and represent money losses (Ceratti et al., 2007).

Less than 5\% indicated that "do not like this products" or "have no interest", which a low percentage and acceptable, since in many situations in life, the diversity of opinions are common.

Evaluating what kind of product they prefer or what can influence their decision in a purchase, $42 \%$ choose the one they like more and only $2.1 \%$ choose a product with the aim to impress. Considering a medium and accessible price, influence the decision of $36 \%$ and $35.5 \%$ keep in mind the preferences of the one that will receive the gift. Among the interviewed, $7.3 \%$ informed that do not use flowers and ornamental plant as a gift. These answers show that only a low percentage does not accept these products as a gift, which is a good result. However, price and personal preferences are important items, which indicated that flower shop may consider and keep this in mind to increase sales.

Consumers were asked about the period of the year that they greatest demand more flowers and ornamental plants, to make sure if it coincides with the period with the greatest demand (commemorative dates) indicated by producers and the retail segment (Figure 7). 


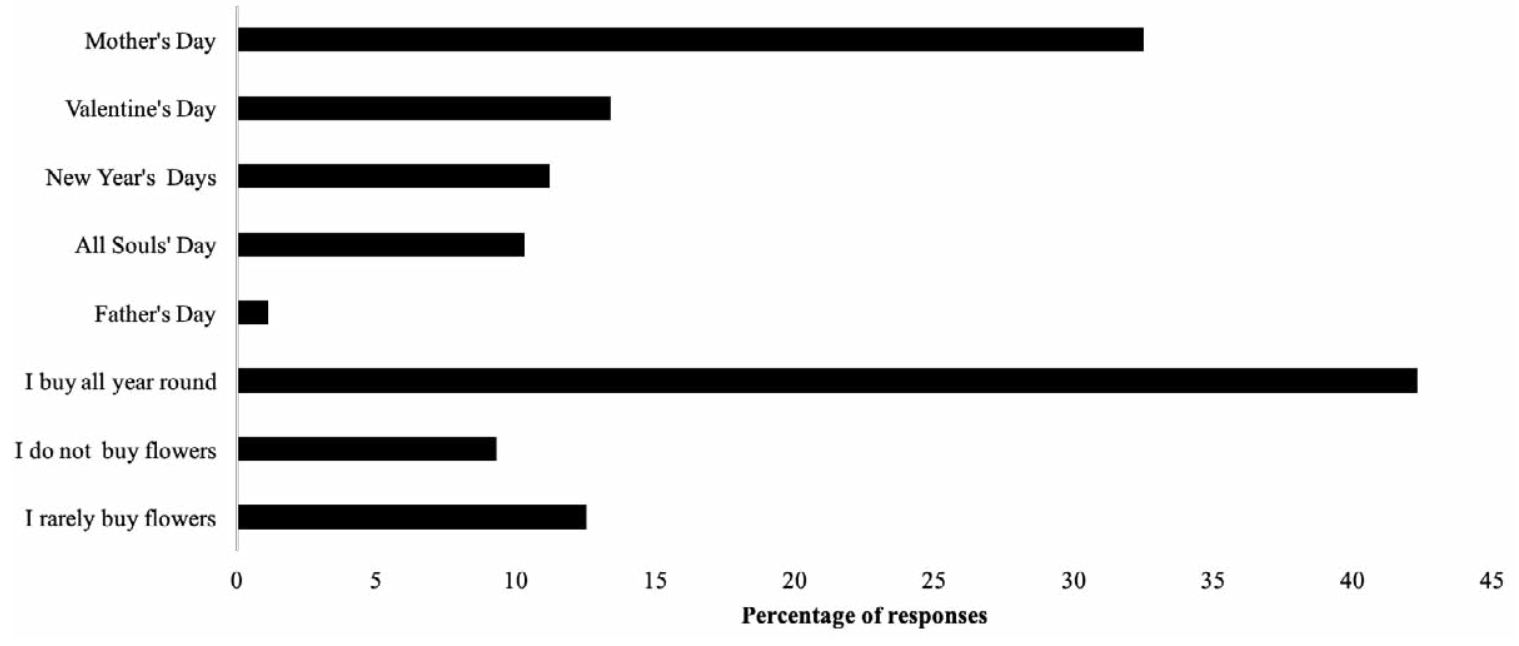

Figure 7. Period of the year with the highest purchase of flowers and ornamental plant according to the consumers' view (multiple responses).

According to the answers, Father's Day has a low percentage of responses $(1.1 \%)$, showing that this is not yet a much explored date by the market. Gifting with flowers is associated with women, although some florists invest in advertising aimed at men, associating flowers with other products, such as craft beers and special coffees, for example.

Unlike what was normally and informally mentioned by retailers it is noted that consumers claim to have the habit of buying flowers all year, regardless of the date. Besides this, it was known that the period of greatest demand for products is concentrated on Mother's Day, followed by Valentine's Day, and Woman's Day. The alternative that indicates the demand for products all year round, obtained only $13.9 \%$ of the answers (Figure 7). This fact can be explained by a lack of perception by consumers when they are induced by the disclosure to buy more during the holidays.

When asked about the place where they usually buy flowers and ornamental plants, $61.5 \%$ of respondents said they prefer flower shops, followed by $37.8 \%$ who said they prefer to buy these products in supermarkets (Figure 8).



Figure 8. Locations preferred by the consumers for buying flowers and ornamental plants (multiple responses) 
One of the reasons for the growth of the flower and ornamental plants market was the introduction of products on the shelves of supermarket chains, which has been exerting strong competition with flower stores, mainly because they offer, in most products, a lower value than florists (Junqueira and Peetz, 2017).

In addition to supermarkets, local fairs (growers market) were also cited as a place of purchase by $20.8 \%$ of consumers interviewed, showing that there is a considerable percentage of local producers, selling flowers and ornamental plants. Consumers have the possibility of buying in these places fresher products, in addition to being able to find different and unusual species.

Shopping stores appear in only $2.1 \%$ of the responses, a fact that can be explained by the high cost of a store in large shopping centers which reflects on the price of the products. One way to maintain the number of sales and facilitate the purchase for the customer is to sell flowers online, through websites and social networks. The survey showed that $3.2 \%$ of the respondents already have this habit.

It was interesting to note that, during the survey, participants were also encouraged to answer whether they knew about the possibility of buying flowers online. Then, $22.8 \%$ said they were unaware of this option, $41 \%$ said they knew, $13.2 \%$ said they knew and used the online service, and only $0.5 \%$ of respondents said they only buy flowers and ornamental plants through the online system (Figure 9). In a survey performed in German, $45.7 \%$ respondents already bought cut flowers online (Rombach et al., 2018), demonstrating evolution and importance of this system.

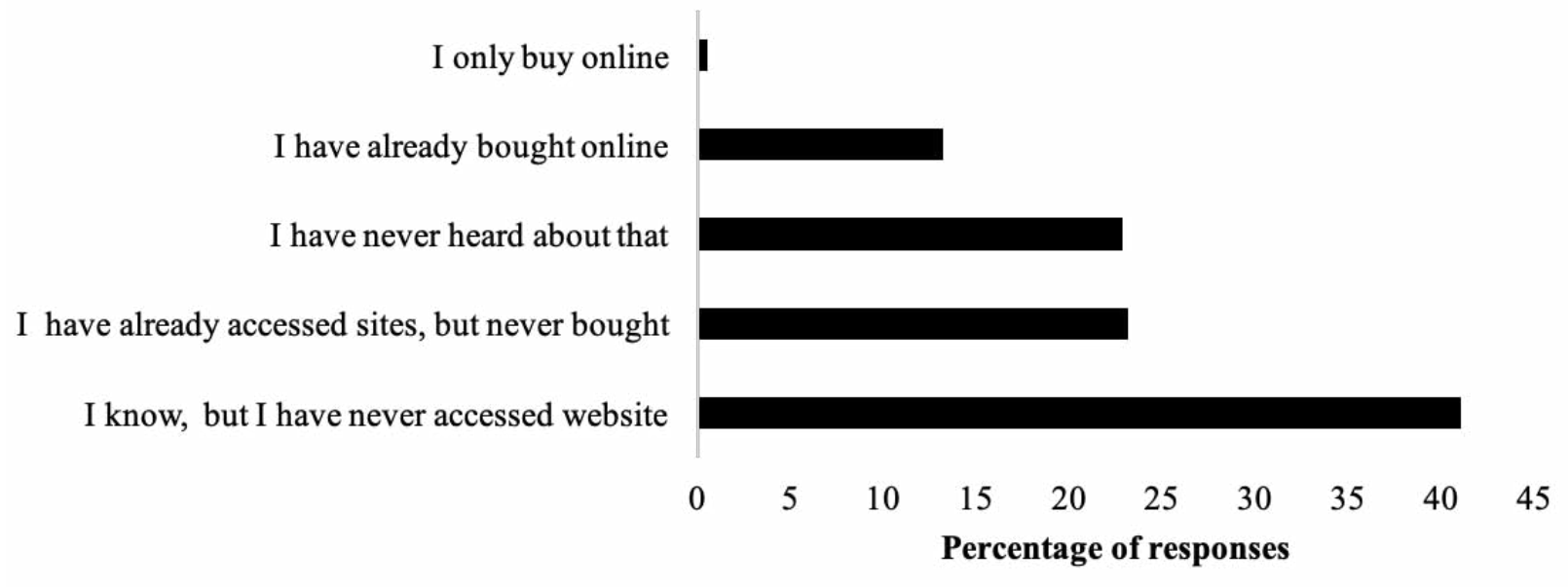

Figure 9. Consumer's knowledge about the online system for flowers and ornamental plant sales (multiple responses).

The flower E-commerce can contribute to the competitive floriculture (Li and Lei, 2016, Schettler et al., 2016). Online flower retailers can be only virtually (with a warehouse) or as a hybrid (with physical and virtual components (Rombach and Bitsch, 2016). The online sales can be made through websites that have a partnership with flower shops from all over the country and abroad, where the customer can choose the product after personal registration and login. The site is in charge of contacting one of the registered stores, which will deliver the product. Another way to buy online is by using the private websites or social media of each flower shop, where the products are exposed by photos and the customer can choose the one that likes best.

Despite the different ways for selling flowers online, Brazil does not show a significant amount of people buying online. This can be explained by the lack of investment by florists in the marketing and modernization of companies' sales systems. Also, to increase the flower E-commerce, the freshness guarantees its importance (Rombach et al., 2018).

Regarding the structure and service of physical stores, the interviewers were asked about what they dislike most during a purchase (Figure 10) and also about what make a flower shop site more pleasant (Figure 10). 


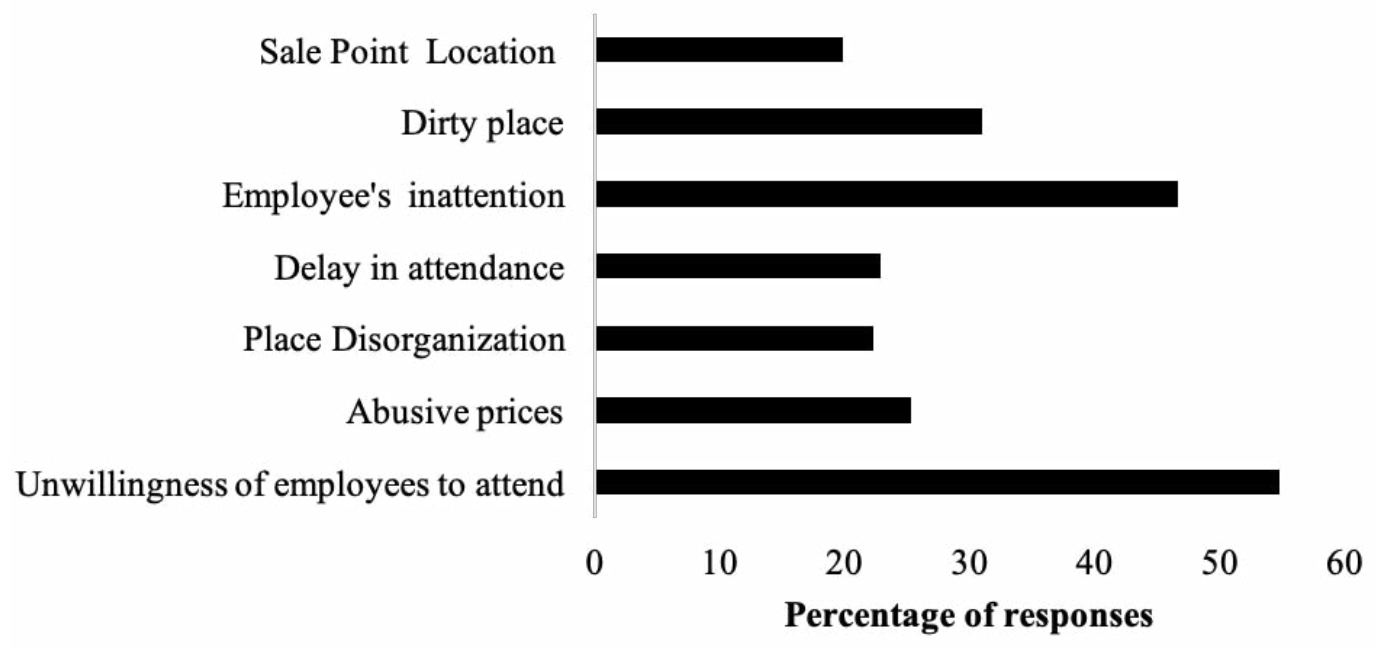

Figure 10. Factors that customers dislike more in flower shops during a purchase (multiple responses).

That is interesting to observe that unwillingness of the employees is the main reason selected by the interviewers $(54.7 \%)$ that make then dislike or disappointed in a purchase process. The abusive/higher prices was the main reason appointed by the elderly (Anacleto et al., 2007b), but concerning all the ages groups, it is a problem for only $25.2 \%$ (Figure 10). The sales point location it is not a problem for most of the interviewers, maybe due to the fact that in the last years increase the diversity of locations, attracting and better attending the clients (Junqueira and Peetz, 2014).
On the other hand, interviewers were asked about the behavior and or situations during a purchase that they most make them feel pleased. The knowledge and capacity of answer questions about the products $(34.2 \%)$ and the attention during the attendance $(22.6 \%)$ are the motivation for in a total $56.8 \%$, showing the importance of the behavior in a client treatment. Only 5.7\% highlight the showcases as an important issue in a flower shop (Figure 11).

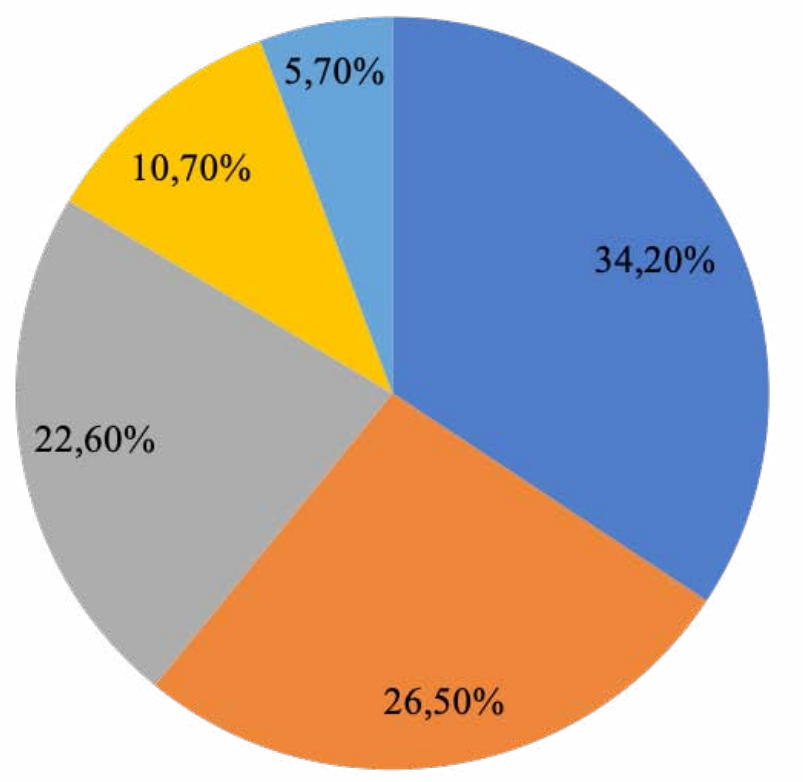
Employees who have knowledge and answer questions

Good prices

Employees' attention during the attendance

Cleaned and organized place

- Products in a beautiful showcases

Figure 11. Factors that please customers in a flower shop during a purchase (multiple responses). 
The behavior, knowledge and operation skill of sale labor plays an important role in attraction, maintenance and loyalty attainment of the customer, more than the price or the product nature and quality since they are able to present and influence a customer on a decision or a purchase (Jandaghi et al., 2011).

In general, what bothers customers the most is the exact opposite of what pleases them most. It should be noticed that $34.2 \%$ of the interviewers, stated that they like being served by employees who knows about the product and are able to answer questions (Figure 11). For $54.7 \%$ of the consumers stated that what bothers them most are employees who are unwilling to attend (Figure 10). This is another factor that significantly influences the consumption of flowers and ornamental plants, mainly because consumers look for products that show affection, romanticism, admiration, etc. Good service is essential for the customer to feel confident in the quality of the product. Indeed, women look for more interaction, tending to be focus on people (Lakshmi et al., 2017)

Also to maintaining customer group of flower E-commerce is necessary keep a "dialogue" and "communication" with consumers (Li and Lei, 2016) what may satisfy and turning them loyal costumers.

In addition to the factors addressed, a very important issue that can influence the consumption of flowers and ornamental plants is the knowledge of consumers about the products offered. Within this context, the consumers were asked about their knowledge in relation to the species names (Figure 12).

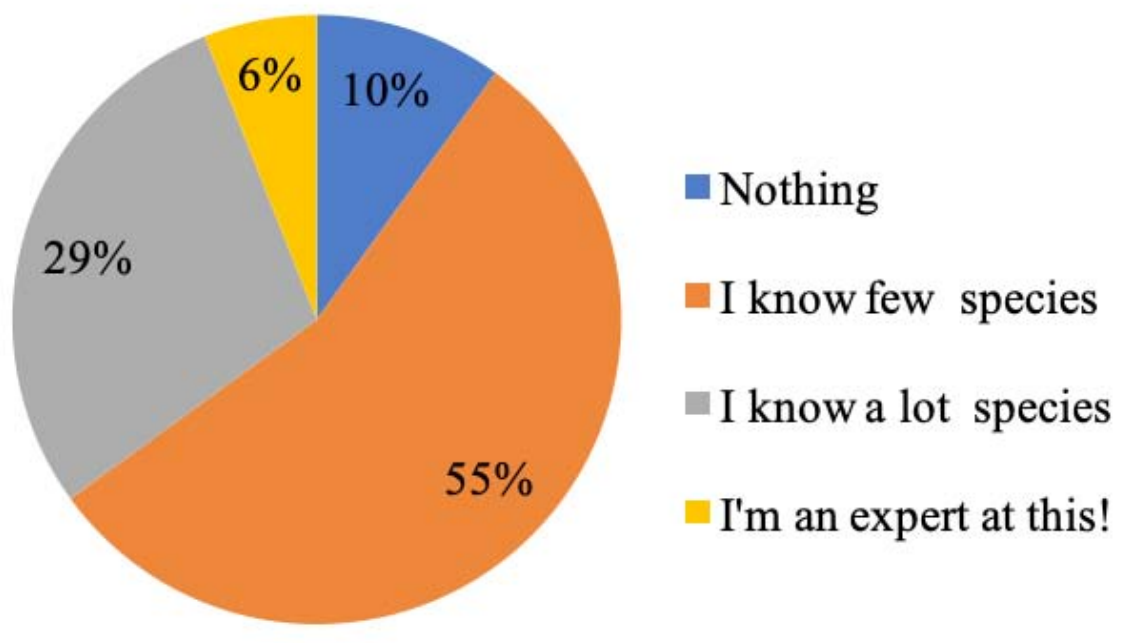

Figure 12. Consumer knowledge about flowers and ornamental plants, according to their opinion.

Most of the responses show that consumers surveyed know nothing $(55 \%)$ or almost nothing $(10 \%)$ about flowers and ornamental plants. On the other hand, when asked what would be interesting in a flower shop, 76.9\% stated that they would appreciate the possibility of taking courses on this subject, offered by the florist/flower shop owner, learning about how to take care of the plants, either in the garden or in decoration vases. But online courses also seem to be interesting, since $42.7 \%$ showed interest in it. This shows that florists/flower shop owners can invest in another profit alternative, as teaching courses which may increases interest and consequently the purchase of customers in products of flowers and ornamental plants.

\section{Conclusions}

The consumption of flowers and ornamental plants is made by women who live in large cities and spend an average of $\mathrm{R} \$ 100.00$ to $\mathrm{R} \$ 200.00$ on the flower and ornamental plant products over a period of one year.
Marketing is done in physical stores, and despite the technology associated with selling products online, a small part of consumption is carried out in this way.

\section{Author contribution}

G.S.S.: survey design, questionnaires application, statistical analyses, results interpretation, manuscript writing. P.D.O.P.: idea, project and survey design, questionnaires application, results interpretation, manuscript writing and review. F.L.B.: results interpretation and manuscript writing. M.V.R.: idea, project and survey design, questionnaires application, results interpretation, manuscript writing and review. P.H.S.G.: statistical analyses and manuscript writing.

\section{Acknowledgements}

The authors are thankful to $\mathrm{CNPq}$, Capes and Fapemig for the scholarships. Thankful to Veiling-Holambra, Cooperflora, Ibraflor, SBFPO, and Nepaflor for help in disseminating the questionnaires. 


\section{References}

ABEP. Associação Brasileira de Empresas de Pesquisa. Critério de classificação econômica Brasil, 2013. Available at: $<$ www.abep.org $>$. Accessed on May, 2020.

AIPH. International Association of Horticultural Producers. Production and Markets - the future of ornamentals. Oxfordshire: International Association of Horticultural Producers, 2019. 51p.

AKI, A. Nichos de mercado para ornamentais. Heliza, 2002.

AKI, A.; PEROSA, J.M.Y. Aspectos da produção e consumo de flores e plantas ornamentais no Brasil. Revista Brasileira de Horticultura Ornamental, v.8, n.1/2, p.1323, 2002.

ANACLETO, A.; FUJITA, E.S.; MENDES, L.P.; VIEIRA, R.M.; PEREIRA, R.T. Profile and behavior of elderly flower consumer in Paraná Coast. Ornamental Horticulture, v.23, n.3, p.337-344. 2017b. DOI: 10.14295/oh.v23i3.1029

ANACLETO, A.; NEGRELLE, R.R.B.; CUQUEL, F.L.; MURARO, D. Profile and behavior of flower consumer: subsidies for marketing actions. Revista Ceres, v.64, n.6, p.557-566, 2017a. DOI: 10.1590/0034-737x201764060001

BOEHM, C. Mesmo com a crise, produção de flores deve crescer 7\% neste ano. Avaiable at: $<$ https://agenciabrasil. ebc.com.br/economia/noticia/2018-09/mesmo-com-criseproducao-de-flores-deve-crescer-7-neste-ano $>$ September $1^{\text {st }} 2018$.

CERATTI, M.; PAIVA, P.D.O.; SOUSA, M.; TAVARES, T.S. Comercialização de Flores e Plantas Ornamentais no segmento varejista no município de Lavras/MG. Ciência e Agrotecnologia, v.31, n.4, p.1212-1218, 2007.

HUSS, E.; YOSEF, K.B.; ZACCAI, M. The meaning of flowers: a cultural and perceptual exploration of ornamental flowers. The Open Psychology Journal, v.10, p.140-153, 2017.

JANDAGHI, G.; AMIRI, A.N.; AMINI, A.; DARANI, M. Assessment and ranking the effects of marketing mix on flower and plant sale volume. International Journal of Academic Research in Business and Social Sciences, v.1, n.3, p.207-219, 2011.

JUNQUEIRA, A.H.; PEETZ, M.S. Brazilian consumption of flowers and ornamental plants: habits, practices, and trends. Ornamental Horticulture, v.23, n.2, p.178-184, 2017. DOI: $10.14295 /$ oh.v23i2.1070
JUNQUEIRA, A.H.; PEETZ, M.S. O setor produtivo de flores e plantas ornamentais do Brasil, no período de 2008 a 2013: atualizações, balanços e perspectivas. Ornamental Horticulture, v.20, n.2, p.115-120, 2014.

LAKSHMI, V.V.; NIHARIKA, D.A.; LAHARI, G. Impact of gender on consumer purchasing behaviour. Journal of Business and Management, v.19, n.8, p.33-36, 2017.

LI, Y.; LEI, M. Analysis on development pattern and marketing strategy of flower E-Commerce of personalized customization - A case study of the beast. Open Journal of Business and Management, v.4, n.1, p.60-66. 2016. DOI: https://doi.org/10.4236/ojbm.2016.41007

LISSITSA, S.; KOL, O. Generation X vs. Generation Y - a decade of online shopping. Journal of Retailing and Consumer Services, v.31, p.304-312, 2016. DOI: https:// doi.org/10.1016/j.jretconser.2016.04.015

OLEWNICKI, D.; JABŁOŃSKA, L.; DUDEK, H. The demand for ornamental plants in Poland after its integration into the EU: a quantitative approach. Bulgarian Journal of Agricultural Science, v.25, n.5, p.932-943, 2019.

PAIVA, P.D.O. Horticulture and Ornamental Horticulture. Ornamental Horticulture, v.24, n.1, p.6, 2018. DOI: http://dx.doi.org/10.14295/oh.v24i1.1169

PALMA, M.A.; HALL, C.R.; COLLART, A. Repeat buying behavior for ornamental plants: a consumer profile. Journal of Food Distribution Research, v.42, n.2, p.6777. 2011.

ROMBACH, M.; BITSCH, V. A typology of online flower shops on the German market. Acta Horticulturae, n.1132, p.127-134. 2016. DOI: https://doi.org/10.17660/ ActaHortic.2016.1132.17

ROMBACH, M.; WIDMAR, N.O.; BYRD, E.; BITSCH, V. Do all roses smell equally sweet? Willingness to pay for flower attributes in specialized retail settings by German consumers. Journal of Retailing and Consumer Services, v.40, p.91-99. 2018. DOI: https://doi.org/10.1016/j. jretconser.2017.09.007

SCHETTLER, C.; ROMBACH, M.; BITSCH, V. Perceived advantages and barriers of buying cut flowers online. Acta Horticulturae, n.1132, p.9-16, 2016. DOI: https://doi. org/10.17660/ActaHortic.2016.1132.2

SILVA, L.C.; PAIVA, P.D.O.; SANTOS, A.C. Flower and ornamental plants wholesale markets in Brazil. Ornamental Horticulture, v.21, n.1, p.53-62, 2015. DOI: 10.14295/rbho.v21i1.776 